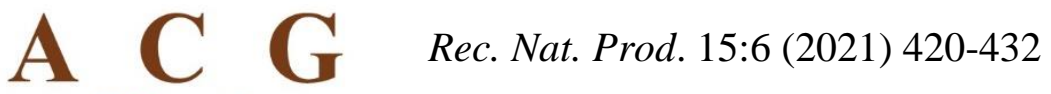 \\ publications
}

\section{Biosynthesis of the Ommochromes and Papiliochromes}

\section{Geoffrey A. Cordell $\oplus^{1,2 *}$ and Sharna-kay Daley $\oplus^{1}$}

\author{
${ }^{\text {I}}$ Natural Products Inc., Evanston, IL 60202, USA \\ ${ }^{2}$ Department of Pharmaceutics, College of Pharmacy, Univesity of Florida, \\ Gainesville, FL 32610, USA
}

(Received February 24, 2021; Revised April 13, 2021; Accepted April 15, 2021)

\begin{abstract}
A brief overview of the biosynthesis of the ommochromes and the papiliochromes is presented.
Keywords: Ommochromes; papiliochromes; alkaloids; tryptophan; dopamine; biosynthesis. ㄷ 2021ACG Publications. All rights reserved.
\end{abstract}

Dedicated to the memory of Professor Ayhan Ulubelen for her extensive contributions to the development of phytochemistry in Turkey and around the world.

"Take time to enjoy the offerings of nature,

Make the best of each emerging day,

For life lingers like the delicate butterfly,

It sort of silently flutters away."

Joseph T. Renaldi

\section{Introduction}

Wherever we look in nature there are alkaloids. They are ubiquitous, enthralling for their benefits, spectacular in their structural diversity and biological properties, and some are disarming to society. Their biosynthesis presents marvelous feats of chemical transformation under notoriously precise enzymatic control evolved over the eons. They challenge each of our senses in profound ways through sight (atropine, betalains), through taste (capsaicin and piperine), through smell (cadaverine), through touch (lyngbyatoxins), and even through sound (dimethyltryptamine). They transform our bodies through a myriad of healing properties (for cancer, infections, headaches, arrythmia, etc.), and they produce some highly profound and deleterious biological effects (morphine, ergotamine, cyclopamine). They alter our minds (psilocin and mescaline) and excite us (adrenaline, caffeine), they bring us calm and tranquility (reserpine, glaziovine), they relieve us of pain (codeine), and they are stunningly lethal (aconitine, batrachotoxin). Here, the focus will be on a small group of alkaloids that stimulate our visual senses and bring us joy, the color principles of insects, and particularly butterfly wings, as well as the colors of many other organisms. These same metabolites also function on behalf of the host, for they are critical components of insect vision, as well as other aspects of their lives. As climate change and habitat loss impacts the range and diversity of the producing organisms, so there is

*Corresponding author: E-Mail:pharmacog@gmail.com.; Phone: 001-847-903-1886 
urgency to assess the chemical nature and the biological function of these important metabolites. This review will provide a brief historical perspective of the studies that have led to a partial understanding of how these alkaloids are formed by their diverse hosts.

\section{Ommochromes}

There are many color pigments in nature which are classified as alkaloids, the betalains of the Centrospermae were mentioned, there are also the pterins, the melanins, and the derivatives of heme. In insects and some other organisms, many colors originate from a group of alkaloid metabolites known as the ommochromes. Reviews of their detection, chemistry, and biosynthesis, and their widespread biological implications and ecological and physiological functions are available [1-4]; the latter review is particularly important for a comprehensive, integrated discussion [4].

The early studies of ommochromes from ommatidia (radial eye elements) were initiated by Becker in the 1930s [5,6], and further pursued by Butenandt's group which explored the chemistry and biogenetic pathway in Drosophila melanogaster, Ephestia kuchniella, Bombyx mori, and Apis mollifera [1]. After these pioneering investigations, it was many years before studies were resumed by chemical ecologists examining the ommochromes associated with vision [7-11], their role in developmental biology and the exquisite patterns of coloring [12], in transcriptomic studies of insects [13-17], their chemical reactivities [18,19], and in genomic editing [20,21]. Two groups of ommochromes are recognized based on the structure of their heterocyclic core unit, those with a phenoxazine (1) (the ommatins) or with a phenthiazine (2) (the ommins) core; almost nothing is known about a third group of metabolites, the ommidins. One of the most well-studied of these metabolites is the yellow xanthommatin (3) [4].

In addition to insect ommatidia, ommochromes are found in cephalopod eyes, and many prostomian integuments [2]. Their colors range from the yellow $\left(\lambda_{\max } 450 \mathrm{~nm}\right)$ of $(3)$, to the red $\left(\lambda_{\max }\right.$ $495 \mathrm{~nm}$ ) of dihydroxanthommatin (4), and the purple $\left(\lambda_{\max } 520 \mathrm{~nm}\right)$ of ommin A (5) (Figure 1), whose structure remains speculative [2,4]. As expected, given the nature of the chromophore, these $\lambda_{\max }$ values are both solvent- and $\mathrm{pH}$-dependent. The overall color response may also be affected through interactions, of a presently uncharacterized nature, with other chromes, such as the pterins and melanins [8,22-24]. Among several ecological roles, ommochromes are involved in color changes and camouflage, including crypsis [11,25-27], in mimicry [28-30], and in sexual maturation [31,32]. It has also been suggested that ommochrome formation is one pathway through which the toxic effects of tryptophan are ameliorated [2].<smiles>[X]c1ccccc1Nc1ccccc1</smiles>

phenoxazine $1, \mathrm{X}=\mathrm{O}$<smiles>NC(CC(=O)c1cccc2oc3cc(=O)c4nc(C(=O)O)cc(O)c4c-3nc12)C(=O)O</smiles>

phenthiazine 2, $\mathrm{X}=\mathrm{S}$

xanthommatin 3<smiles>NC(CCc1cccc2c1Nc1c(cc(O)c3nc(C(=O)O)cc(O)c13)O2)C(=O)O</smiles>

dihydroxanthommatin 4<smiles>NC(CC(=O)c1cccc2[nH]c3cc4sc5cccc(C(=O)CC(N)C(=O)O)c5[nH]c4c(C(=O)CC(N)C(=O)O)c3[nH]c12)C(=O)O</smiles>

ommin A 5

Figure 1. Structures of compounds 1-5 
Studies of eye-color mutants of D. melanogaster contributed significantly to understanding the fundamentals of gene-enzyme relationships [33] and cellular interactions during development [34]. More recently, studies of ommochromes have led to a greater understanding of how animal color patterns develop $[12,35,36]$. As analytical techniques have improved in the past twenty-five years other sources of ommochromes have been discovered, including crab spiders [37], silkworms [38], dragonflies [32], and cephalopods [27].

Ommochromes are challenging metabolites to study because of the minute quantities typically available, and because they are difficult to solubilize, they also tend to aggregate, and readily undergo both reversible and non-reversible transformations requiring rapid processing [2,3,39]. Extraction techniques (e.g., acidic methanol) conducted in the air and at room temperature can induce degradation in the ommochromes $[2,4,31]$, especially resulting in decarboxylation of the pyridine ring $[18,19]$. Recent applications of HPLC [26,37] and mass spectrometric data have aided significantly in delineating the authentic metabolites in extracts, as distinct from processing artefacts [27,32,40,41]. It was suggested that a community-based library of MS data of ommochromes be created [42]. Because of their instability, purified samples for biological evaluation are not commercially available, and thus either de novo synthesis or isolation from specific sources (e.g., Calliphora erythrocephalis eyes for (3)) are necessary to conduct biological studies.

\section{Ommochrome Biosynthesis}

The ommochromes arise through the catabolism of L-tryptophan (6) $[2,4]$. However, only the formation of xanthommatin (3) has been studied in detail. Three, widely distributed enzymes are responsible for the catabolism of (6) to 3-hydroxykynurenine (7): tryptophan 2,3-dioxygenase (TDO), kynurenine formamidase (KFase), and kynurenine 3-hydroxylase. 3-Hydroxykynurenine (7) is known to be an intermediate in the formation of xanthurenic acid (8), and kynurenine (9) leads to kynurenic acid (10). The former intermediate also leads to the papiliochromes (vide infra) [43], and to the precursor of numerous alkaloids, anthranilic acid (11). These early pathway steps are summarized in Scheme $1[4]$.

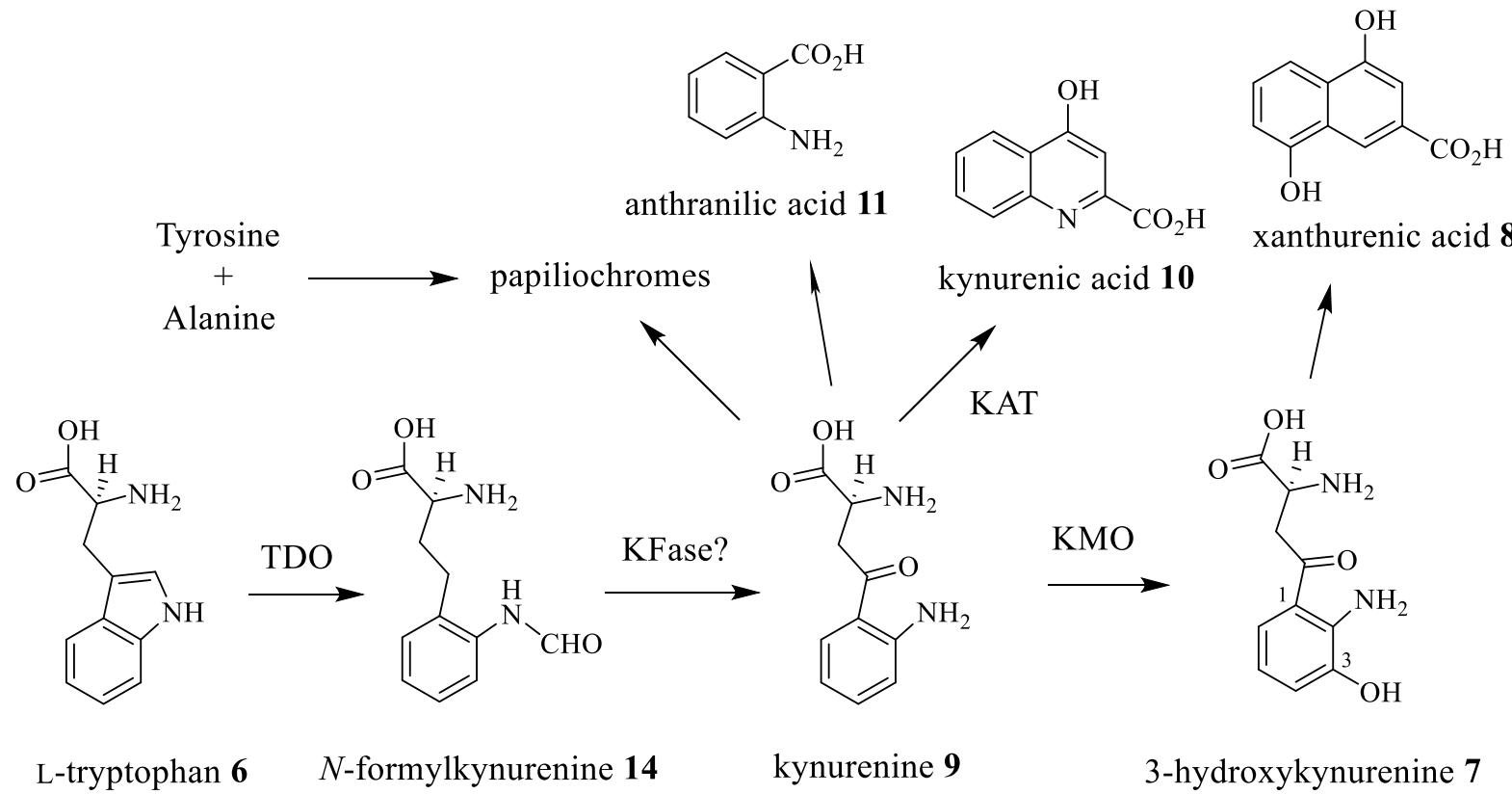

Scheme 1. Catabolism of L-tryptophan (6) to 3-hydroxykynurenine (7)

Studies on the biosynthesis of the ommochromes in insects were initiated in the late 1950s, by Inagami who disclosed the presence of kynureninase [44,45], by Glassman who detected kynurenine formamidase (KFase) in insect homogenates [46], and by Egelhaaf [47] and Baglioni [48] who showed 
the presence of tryptophan 2,3-dioxygenase (TDO) in Drosophila. These early studies were reviewed in detail by Linzen [2] and are briefly summarized.

Steadily enhanced partial purification of tryptophan 2,3-dioxygenase (TDO, formerly tryptophan pyrrolase) was achieved by various groups [49-52], and the Drosophila TDO enzyme was estimated to be about $150 \mathrm{kDa}$ [52]. The enzyme velocity was concentration-dependent, as had been observed for the microbial enzyme [53]. Inhibition of the enzyme (>50\%) was observed in the presence of $\mathrm{Cu}^{2+}$, hydroxylamine, and 2-amino-4-hydroxy-6-hydroxymethylpteridine [2,4]. The specific activity of the Drosophila enzyme was regarded as comparable to that from rat liver, although activities varied between different strains of D. melanogaster [54,55]. The enzyme distribution pattern in the host is quite different, however. Limited in vertebrates to the liver, in insects it has been found in many diverse tissues and segments $[2,4]$. There is an indication of inducibility by the addition of $(\mathbf{6})$ in Drosophila [56-58], however, in Ephestia moths [59], Habrobracon wasps [60], and Phormia flies [2], this is not the case. Also, as first reported by Glassman from Drosophila melanogaster and D. virilis [46], kynurenine formamidase (KFase) was found in essentially every tissue of the cricket Gryllus bimaculatus and the silkworm Bombyx mori that was examined (cited in ref 2). Although the enzyme from rat liver was first purified in 1970 [61], it does not seem to have been compared directly with the insect enzyme.

Kynurenine hydroxylase (or 3-monooxygenase) (KMO) was recognized as being light-sensitive [62], and this hampered functional studies. Direct observations of activity were measured through the injection of kynurenine (9) into Ephestia moths and monitoring of the product $[59,63]$. The enzyme is localized in the mitochondria in many insect body parts [64,65]. There is a requirement for NADPH, and strong inhibition by $\mathbf{3}$ was observed for a preparation from bees [2].

The ready availability of 2-aminophenols, a functional aspect of 7 , led to many studies, particularly by Butenandt's group [2], of the different products derived from their oxidation under a variety of conditions. Considering the diverse product outcomes, the enzymes should be highly specific, for both the substrate and the regiospecificity of the reaction performed. The enzymes responsible for these oxidations were initially obtained from microbial and plant [66-69], and vertebrate (rat liver) [7073] sources. An interesting observation made by Butenandt was that 7 in the presence of the tyrosinase from the blow fly, Calliphora sp., yielded xanthommatin (3) only in the presence of DOPA [74]. Although a non-insect-derived tyrosinase could convert 7 to 3 in the absence of DOPA [75]. The derivatives of dihydroxanthommatin (4), such as rhodammatin (12) and ommatin D (13), could arise through the direct $O$-methylation and sulfonation of (4), respectively. Rhodammatin (12) was labeled in the larvae of the butterfly Argynnis paphia by 3, although $\mathbf{1 3}$ was not [2].

The biosynthesis of the widely distributed ommins and ommidins, which contain a phenthiazine ring $[2,4,76]$, is poorly understood. Early efforts to identify unambiguously the source of the sulfur atom (methionine, cysteine, sulfate, sulfide) were unsuccessful [77]. More recent investigations $[4,78]$ did indicate the possible involvement of methionine and cysteine as sources of the sulfur atom, but where in the process and the mechanism of introduction are unknown. Studies on the eggs of the silkworm B. mori indicated the significance of a heme-peroxidase-encoding gene in the concluding steps of ommatin and ommin biosynthesis [38,79].

Since these seminal studies on the ommochromes and their biosynthesis there has been significant progress made in understanding the enzymes and the processes involved. Two of the pathway steps to (3) may not involve enzyme mediation, namely, the loss of the $\mathrm{N}$-formyl group of $\mathrm{N}$ formylkynurenine (14), and the cyclization of the aspartyl-like chain of the kynurenine dimer. In this latter regard, cold-extraction (butanol-acid) of insects (Apis, Musca), cephalopods (Octopus, Sepia, Loligo), and crustaceans (Homarus) afforded a metabolite, possibly 15 ( $\left.\lambda_{\max } 450,430\right)$, which, at room temperature, cyclized rapidly to the red dihydroxanthommatin $(4)\left(\lambda_{\max } 498,385\right)$, and then oxidized in air to $3\left(\lambda_{\max } 460,385\right)$ [80]. The question therefore remains whether 3 is a metabolite or an artefact derived during the processing of $\mathbf{1 5}$ as illustrated in Scheme 2. Discussion of this issue in the biosynthesis of $\mathbf{3}$ has continued for at least 50 years [81-84].

An important aspect of the study of ommochrome biosynthesis has been the development of mutant strains $[2,4]$. In the case of $D$. melanogaster, three gene mutants, vermilion, cinnabar, and cardinal have been important [79]. A detailed summary of these mutants and their relationship to the enzymes for the formation of 7 and its further development in insects is available [4]. These genes have also been characterized in planarians (fresh-water flatworms) $[85,86]$. 


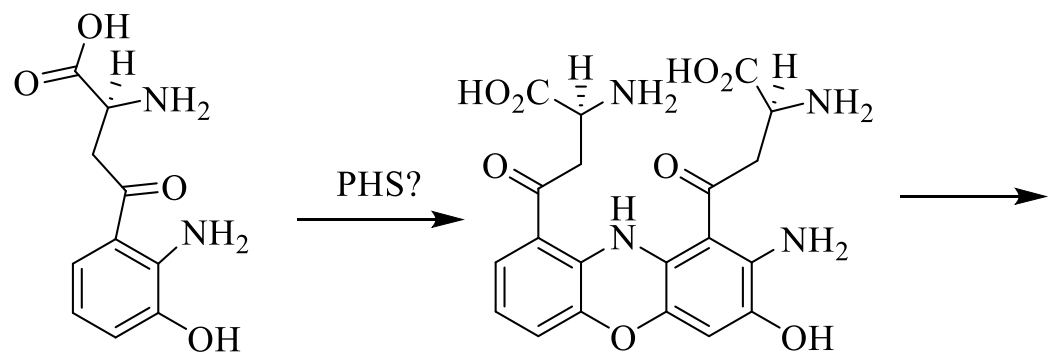

3-hydroxykynurenine 7
15<smiles>N[C@@H](CC(=O)c1cccc2c1Nc1c(cc(O)c3nc(C(=O)O)cc(O)c13)O2)C(=O)O</smiles>

dihydroxyxanthommatin 4<smiles>[R2]c1cc2c(c3c(O)ccnc13)Nc1c(cccc1C(=O)CC(N)C(=O)O)O2</smiles>

rhodommatin 12, $\mathrm{R}=\mathrm{CH}_{3}$ ommatin $\mathrm{D} 13, \mathrm{R}=\mathrm{SO}_{3}{ }^{-}$

$$
\begin{aligned}
& \text { xanthommatin } 3, \mathrm{R}=\mathrm{CO}_{2} \mathrm{H} \\
& \text { decarboxyxanthommatin 16, } \mathrm{R}=\mathrm{H}
\end{aligned}
$$

Scheme 2. Biogenesis of xanthommatin (3) and derivatives

The crystal structure of the tryptophan 2,3-dioxygenase (TDO), encoded by the vermilion gene, was reported in 2013 [87] to be a tetrameric complex, and information regarding the conserved sequences between variously sourced enzymes has been summarized [88]. For kynurenine formamidase (KFase) there are no isolated mutants from insects, which may indicate that the deformylation step does always require a catalyst, since $\mathbf{1 4}$ is unstable. The KFase enzyme was characterized from $D$. melanogaster [89], where it possibly enhances the availability of $\mathbf{9}$. The cinnabar gene in $D$. melanogaster acts to produce $\mathrm{FADH}_{2}$, which, in the presence of $\mathbf{9}$ forms 3-hydroxykynurenine (7) and FAD for recycling [90]. The KMO enzymes from yeast and Pseudomonas have been crystallized [9092], however, there are no examples from insect sources. The KMO enzymes have drug discovery potential for a number of important neurodegenerative or neuroinflammatory diseases, including Alzheimer's, Parkinson's, and Huntington's diseases [90]. The involvement of a phenoxazone synthase (PHS) as the first committed step in ommochrome biosynthesis remains controversial [93], and some studies have indicated that PHS is not involved in the dimerization of (7) [84]. Mutation of the cardinal gene, which encodes for a heme peroxidase, in D. melanogaster, B. mori, and Tribolium castaneum led to the accumulation of (7) [38,94], implying the presence of an enzyme processing for ommochrome formation. The formation of dihydroxanthommatin (4) also is unclear, with several scenarios described, including a possible specific reductase [95]. On the other hand, there has been no success in isolating a reductase for the $\mathbf{3}$ to $\mathbf{4}$ transformation, while the reverse reaction is very rapid in air at room temperature. The overall scheme for xanthommatin 3 and ommochrome biosynthesis is shown in Scheme 2 [4].

The location of the enzymes in various tissues is highly diverse. The soluble fraction of the cells contains the TDO and the KFase, whereas the KMO is located in the outer membrane of the mitochondria. This implies that transporters are available to move substrates between the various organs. In the mosquito Aedes aegyptii, 3-hydroxykynurenine (7) is converted to xanthurenic acid (8) during the larval development stage and is transported to the compound eyes during the pupal development phase for ommochrome formation, which apparently occurs without enzyme assistance [84].

Colorations of the eggs of the silkworm Bombyx mori are also different depending on the encoded ommochrome enzymes. For example, genetic studies revealed that that the red egg (re) mutant, having pale orange eggs, rather than brownish lilac eggs, was derived through the insertion of a transposable element (Bm-re) which blocked the late stages of ommochrome biosynthesis [76]. 
Homologs of the same gene were found in all insect genomes, except for Drosophila, and knockout studies of the homologous gene produced eye colorant defects in the red flour beetle T. castaneum. The gene involved in the pink-eyed white egg (pe) B. mori mutant was an ortholog of the peroxidase cardinal gene in D. melanogaster [38]. Knock-out studies in T. castaneum also produced red compound eyes, signifying the importance of the encoded cardinal gene product in ommochrome formation.

Using several egg color mutants and wild-type strains, ommochromes and their precursors were detected in both diapause and non-diapause eggs. As expected, 3-hydroxykynurenine (7), and not the ommochromes accumulated in the yellow egg mutants ( $w-2$ and pe). During the diapause phase, the levels of decarboxyxanthommatin (16) and $\mathbf{3}$ increased, and ommochrome pigments were converted into their reduced forms [78]. Levels of $\mathbf{1 6}$ were typically higher than $\mathbf{3}$ in silkworm eggs.

The ommochromes are widespread in nature and have several species-specific biological functions, including for vision, for cell homeostasis and amino acid detoxification, and for variable skin coloration [4]. The nucleus offers synthetic chemists a potent scaffold for building a variety of colorizing agents. More studies are needed which examine the interrelationships between different color pigment pathways and how they are controlled, and how their individual and delicate chemistry has both ecological and cell biology implications.

\section{Papiliochromes}

The spectacular coloration of butterfly wings had fascinated natural product chemists for a long time. Nijhout [96] summarized how different butterfly families relied on structurally and biosynthetically different alkaloids for their wing color pigments. The pterins were present in the Pieridae, the ommochromes in the Nymphalidae, and the papiliochromes in the Papilionidae.

Initial studies on the wing color metabolites from swallow-tail butterflies in the Papilionidae were conducted by Umebachi at Kanezawa University, Japan, beginning in 1954. In a seminal report, it was disclosed that kynurenine (9) was present to a significant extent in a hot water extract of the yellow scales of papilionid butterflies [97,98].

A series of papers followed with studies focused on the chromes of Papilio muthus, and the presence of kynurenine (9) in other butterfly genera in the family was firmly established [99-104]. ${ }^{14} \mathrm{C}-$ Labeled tryptophan (6) was incorporated into the wing metabolites in five species of Papilio [101], and free and bound kynurenine (9) and tryptophan 2,3-oxidase (TDO, tryptophan pyrrolase) levels were traced through the pupal stages of $P$. xuthus [105,106]. Notably, related metabolites of (9), including $N$-formylkynurenine (14), $N^{\alpha}$-acetylkynurenine, kynurenic acid (10), and anthranilic acid (11), were absent, and 3-hydroxykynurenine (7)was present only in small amounts.

Two other metabolites were shown to be present, the yellow papiliochromes II and III, which were hydrolyzed with acid to afford 9 and a phenolic derivative [103]. Further studies [107] separated each of these into two metabolites; the papiliochromes IIa and IIb had opposite circular dichroism curves. Labeled tryptophan (6), DOPA (17), and dopamine (18) were injected into the prepupa, drawing the conclusion that the papiliochromes were derived from dopamine (18) and kynurenine (9) [107].

On mild acid hydrolysis, the two isomers of papiliochrome II (19) each produce 9 and a second product designated as SN-1 [107-110]. When subjected to more aggressive acid hydrolysis SN-1 afforded $\beta$-alanine (20) and a dopamine derivative [108]. SN-1 incorporated label from $\left[{ }^{14} \mathrm{C}\right]-\beta$-alanine (20) when injected at the pharate pupal stage. Further work substantiated these relationships, and indicated that $\left[{ }^{14} \mathrm{C}\right]$ tryptophan $(\mathbf{6})$ was incorporated into $\mathbf{1 9}$ and $\mathbf{9}$, and that $\left[{ }^{14} \mathrm{C}\right]$ dopamine $\mathbf{1 8}$ was incorporated into 19, and SN-1 [111]. Finally, in 1984, after 30 years of study, the structure of papiliochrome II was deduced to be the two diastereomers of $N^{\text {ar }}$-[ $\alpha$-(3-aminopropionylaminomethyl)3,4-dihydroxybenzyl]-L-kynurenine (19) [112]. It was proposed that the yellow color was due to interactions between the stacked aromatic ring systems. The isolation and chemical studies were reviewed at this time [43]. 
<smiles>[R17]Nc1c([R2])cccc1C(=O)C[C@H](N)C(=O)O</smiles>

kynurenine 9, $\mathrm{R}=\mathrm{H}, \mathrm{R}_{2}=\mathrm{H}$

$\mathrm{N}$-formylkynurenine $\mathbf{4}$,

$$
\mathrm{R}_{1}=\mathrm{CHO}, \mathrm{R}_{2}=\mathrm{H}
$$

3-hydroxy-kynurenine 7 ,

$$
\mathrm{R}_{1}=\mathrm{H}, \mathrm{R}_{2}=\mathrm{OH}
$$<smiles>[H][R]([H])(O)C(N)(CC(=O)c1ccccc1N[C@@H](CNC(=O)CCN)c1ccc(O)c(O)c1)C(=O)O</smiles>

papiliochrome II 19<smiles>N[C](Cc1c[nH]c2ccccc12)C(=O)O</smiles>

\section{L-tryptophan 6}<smiles>NCCC(=O)O</smiles>

beta-alanine $\mathbf{2 0}$<smiles>[R]C(N)(N)Cc1ccc(O)c(O)c1</smiles>

DOPA $17, \mathrm{R}=\mathrm{CO}_{2} \mathrm{H}$

dopamine $18, \mathrm{R}=\mathrm{H}$<smiles>[R]C(CNC(=O)CCN)c1ccc(O)c(O)c1</smiles>

$N$-beta-alanyl dopamine $21, \mathrm{R}=\mathrm{H}$

$\mathrm{N}$-beta-alanyl noradrenaline 22, $\mathrm{R}=\mathrm{OH}$

Figure 2. Structures of compounds 6,7,9,14, and 17-22

Metabolite studies by Ishizaki and Umebachi [113-115] indicated that kynurenine (9) and $N$ - $\beta$ alanyldopamine (21) are produced in the hemolymph, and then transported to the wings of $P$. xuthus for 19 formation. Attention then turned to the enzymes involved in the formation of 19. An enzyme preparation from the colleterial gland of the praying mantis, Tenodera aridifolia sinensis, hydroxylated the $\beta$-carbon of $N$-acyldopamine. In addition, incubation with $N$ - $\beta$-alanyldopamine $(\mathbf{2 1})$ and Lkynurenine (9) afforded 19 [116], and silk and pupal cuticle preparations from the Japanese giant silkmoth Dictyoploca japonica also possessed this activity.

The pale-yellow pigment, papiliochrome II was identified in many other Papilio species, including $P$. castor, $P$. dardanus, $P$. demoleus, $P$. helenus, $P$. polytes, and $P$. protenor. It forms Lkynurenine (9) and $N$ - $\beta$-alanylnoradrenaline (22) on mild acid hydrolysis [117]. Investigation of the other pigments indicated that papiliochrome M $[43,109]$ was also composed of $\mathbf{9}, \mathbf{1 8}$, and $\mathbf{2 0}$, with an additional unit of $\mathbf{2 0}$ compared with $\mathbf{1 9}$ (Figure 2). No final structure was proposed, and similarly, the structure of the reddish-brown analog papiliochrome $\mathrm{R}$ also remains unknown [117].

While Umebashi and colleagues had defined the structure and the precursor units of $\mathbf{1 9}$, the mechanism of formation was unknown until Sugurmaran and co-workers examined the pathway intermediates. Using $N$-acetylcysteine (23) as a trapping agent in the adult fleshfly Sarcophaga bullata, $N$ - $\beta$-alanyldopamine (21) was metabolized to the $N$ - $\beta$-alanyldopamine-quinone- $N$-acetylcysteine adduct (24) (Figure 3) and no $N$ - $\beta$-alanylnoradrenaline (22) was produced [118].<smiles>CC(=O)NC(CS)C(=O)O</smiles>

23<smiles>CC(=O)NC(CSC1=CC(CCNC(=O)CCN)=CC(=O)C1=O)C(=O)O</smiles>

Figure 3. Structures of compounds 23 and 24 
The implication was that a quinone methide intermediate, such as $\mathbf{2 5}$, was involved as an oxidized intermediate from 21. An enzyme isolated from the cuticle could conduct the same reaction, and in the presence of $\mathbf{9}$ produced the diastereoisomers of 19. The apparent absence of enzymatic control over this nucleophilic attack was noted. A two-step process from (21) was therefore proposed to involve oxidation to the ortho-quinone (26) by a phenoloxidase, followed by a quinone isomerase (a tautomerase) to generate the quinone methide (25) which is then susceptible to Michael-type addition by the aromatic amino group of 9 [118]. Mushroom tyrosinase, in reaction with the quinone isomerase and $\mathbf{2 1}$ in the presence of $\mathbf{9}$, also afforded the diastereoisomers of $\mathbf{1 9}$, indicating the last step as a nonspecific enzymatic process [119]. Parallel results were obtained for the formation of $\mathbf{1 9}$ using an enzyme preparation from the cuticle of the tobacco hornworm, Manduca sexta [120]. The pathway for the formation of the diastereoisomers of 19 from 18, 20, and 9 is shown in Scheme 3. Further study revealed that the levels of $\beta$-alanyldopamine synthase (BAS), the enzyme which transfers $\beta$-alanine (20) to 18, were high in females of $P$. glaucus when 19 formation was producing the yellow wing pigment, and that DOPA decarboxylase was similarly high [121]. On the other hand, in the phenotype producing the brown melanic wings, BAS was almost absent, and consequently it was proposed that BAS was a regulator of 19 formation. A review of insect pigments offers a brief summary of papiliochrome biosynthesis while discussing a broad range of insect chrome structures [122].<smiles>NCCCC(=O)O</smiles>

dopamine 18<smiles>NCCC(=O)NC[C@H](Nc1ccccc1C(=O)CC(N)C(=O)O)c1ccc(O)c(O)c1</smiles>

papiliochrome II 19<smiles>NCCC(=O)NCCc1ccc(O)c(O)c1</smiles>

$N$-beta-alanyldopamine $\mathbf{2 1}$

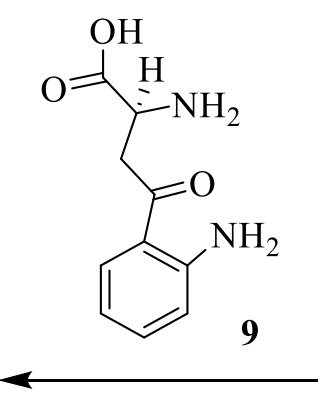

Scheme 3. Biosynthesis of papiliochrome II (19).

\section{Conclusions}

This summary of the historical background to studies of the formation of the ommochromes and the papiliochromes has highlighted some aspects of the progress made in understanding the biosynthesis of these alkaloids; metabolites which provide so many natural color pigments. As the chemical and biological technologies have advanced so they have been applied in this area of natural product chemistry. The result is a clearer comprehension of many of the fundamental processes for the formation and the functioning of the ommochromes and papiliochromes. However, significant questions of detail remain in the ommochrome biosynthetic pathway, particularly with respect to the final steps, and establishing the evolutionary and ecological significance of these alkaloids at the gene level. There are also important questions regarding the ommidins and their structures and functions, and of the biological importance of the interactions between other color pigments and the ommochromes. For the papiliochromes, the complexity of the metabolites, the diversity of the coloration patterns, and their 
stability merits exploration for potential stabilization and selective use as natural colorants. Finally, the importance of these alkaloids in terms of species survival should be explored through integrated approaches based on chemical biology as climate change and biodiversity losses affect the range and the survival of their host species.

\section{ORCID}

Geoffrey A. Cordell: 0000-0003-2536-3097

Sharna-kay Daley: 0000-0002-5927-6250

\section{References}

[1] A. Butenandt and W. Schäfer (1962). Ommochromes. In: Recent Progress in the Chemistry of Natural and Synthetic Colouring Matters and Related Fields, ed:T.S. Gore, B.S. Joshi, S.V. Sunthankar and B.D. Tilak, Academic Press, New York, NY, USA, pp. 13-33.

[2] B. Linzen (1974). Tryptophan to ommochrome pathway in insects, Adv. Insect Physiol. 10, 117-246.

[3] A. E. Needham (1974). The Significance of Zoochromes. Springer-Verlag, Berlin, Germany, pp. 452.

[4] F. Figon and J. Casas (2019). Ommochromes in invertebrates: biochemistry and cell biology, Biol. Rev. 94, 156-183.

[5] E. Becker (1939). Über die Natur des Augenpigments von Ephestia kuhniella und seinen vergleich mit den Aaugenpigmenten anderer insekten, Biol. Zbl. 59, 597-627.

[6] E. Becker (1942). Über eigenschaften, verbreitung und die genetischentwicklungs-physiologische bedeutung der pigmente der ommatin-und ommingruppe (ommochrome) bei den arthropoden, Mol. Gen. Genet. 80, 157-204.

[7] G.S. Oxford and R.G. Gillespie (1998). Evolution and ecology of spider coloration, Annu. Rev. Entomol. 43, 619-643.

[8] D.G. Stavenga (2002). Colour in the eyes of insects, J. Comp. Physiol. A 188, 337-348.

[9] M. Théry and J. Casas (2009). The multiple disguises of spiders: web colour and decorations, body colour and movement, Phil. Trans. Roy. Soc. B: Biol. Sci. 364, 471-480.

[10] K.D.L. Umbers, S.A. Fabricant, F.M. Gawryszewski, A.E. Seago and M.E. Herberstein (2014). Reversible colour change in Arthropoda. Biol. Rev. 89, 820-848.

[11] R. Futahashi (2016). Color vision and color formation in dragonflies, Curr. Opin. Insect Sci. 17, 32-39.

[12] T. Sekimura and H.F. Nijhout (2017), eds: Diversity and evolution of butterfly wing patterns: An integrative approach, Springer Open, Singapore, pp. 333.

[13] P.J. Croucher, M.S. Brewer, C.J. Winchell, G.S. Oxford and R.G. Gillespie (2013). De novo characterization of the gene-rich transcriptomes of two color-polymorphic spiders, Theridion grallator and T. californicum (Araneae: Theridiidae), with special reference to pigment genes, BMC Genom. 14, 862.

[14] P. Chauhan, B. Hansson, K. Kraaijeveld, P. de Knijff, E.I. Svensson and M. Wellenreuther (2014). De novo transcriptome of Ischnura elegans provides insights into sensory biology, colour and vision genes, BMC Genom. 15, 808.

[15] H. Connahs, T. Rhen and R.B. Simmons (2016). Transcriptome analysis of the painted lady butterfly, Vanessa cardui during wing color pattern development, BMC Genom. 17, 270.

[16] Z. Qiu, F. Liu, H Lu and Y. Huang (2017). Characterization and analysis of a de novo transcriptome from the pygmy grasshopper Tetrix japonica, Mol. Ecol. Res. 17, 381-392.

[17] P. Wang, Z. Qiu, D. Xia, S. Tang, X. Shen and Q. Zhao (2017). Transcriptome analysis of the epidermis of the purple quail-like ( $l^{p}$ ) mutant of silkworm, Bombyx mori. PLoS One 12, e0175994.

[18] A. Bolognese, R. Liberatore and G. Scherillo (1988). Photochemistry of ommochromes and related compounds, J. Het. Chem. 25, 979-983.

[19] A. Bolognese, R. Liberatore and G. Scherillo (1988). Photochemistry of ommochromes and related compounds. Part II, J. Het. Chem. 25, 1251-1254.

[20] S.A. Khan, M. Reichelt and D.G. Heckel (2017). Functional analysis of the ABCs of eye color in Helicoverpa armigera with CRISPR/Cas9-induced mutations, Sci. Rep. 7, 40025.

[21] W.-H. Xue, N. Xu, X.-B. Yuan, H.-H. Chen, J.-L. Zhang, S.-J. Fu, C.-X. Zhang and H.-J. Xu (2017). CRISPR/Cas9-mediated knockout of two eye pigmentation genes in the brown planthopper, Nilaparvata lugens (Hemiptera: Delphacidae), Insect Biochem. Mol. Biol. 93, 19-26.

[22] S. Fuzeau-Braesch (1985). Colour changes. In: Comprehensive Insect Physiology, Biochemistry and Pharmacology, eds: G.A. Kerkut and L.I. Gilbert, Pergamon Press, Oxford, UK, pp. 549-590.

[23] D.G. Stavenga, H.L. Leertouwer and B.D. Wilts (2014). Coloration principles of nymphaline butterflies - thin films, melanin, ommochromes and wing scale stacking, J. Exptl. Biol. 217, 2171-2180. 
[24] B.D. Wilts, A.J.M. Vey, A.D. Briscoe and D.G. Stavenga (2017). Longwing (Heliconius) butterflies combine a restricted set of pigmentary and structural coloration mechanisms, BMC Evol. Biol. 17, 226.

[25] T.C. Insausti and J. Casas (2008). The functional morphology of color changing in a spider: development of ommochrome pigment granules, J. Exptl. Biol. 211, 780-789.

[26] A.L. Llandres, F. Figon, J.-P. Christides, N. Mandon and J. Casas (2013). Environmental and hormonal factors controlling reversible colour change in crab spiders, J. Exptl. Biol. 216, 3886-3895.

[27] T.L. Williams, C.W. DiBona, S.R. Dinneen, S.F. Jones Labadie, F. Chu and L.F. Deravi (2016). Contributions of phenoxazone-based pigments to the structure and function of nanostructured granules in squid chromatophores, Langmuir 32, 3754-3759.

[28] R.D. Reed, W.O. McMillan and L.M. Nagy (2008). Gene expression underlying adaptive variation in Heliconius wing patterns: non-modular regulation of overlapping cinnabar and vermilion prepatterns, Proc. Roy. Soc. B: Biol. Sci.275, 37-46.

[29] L.C. Ferguson and C.D. Jiggins (2009). Shared and divergent expression domains on mimetic Heliconius wings, Evol. Devel. 11, 498-512.

[30] S.M. Bybee, F. Yuan, M.D. Ramstetter, J. Llorente-Bousquets, R.D. Reed, D. Osorio and A.D. Briscoe (2012). UV photoreceptors and UV-yellow wing pigments in Heliconius butterflies allow a color signal to serve both mimicry and intraspecific communication, Am. Natur. 179, 38-51.

[31] H.F. Nijhout (1997). Ommochrome pigmentation of the linea and rosa seasonal forms of Precis coenia (Lepidoptera: Nymphalidae), Arch. Insect Biochem. Physiol. 36, 215-222.

[32] R. Futahashi, R. Kurita, H. Mano and T. Fukatsu (2012). Redox alters yellow dragonflies into red, Proc. Natl. Acad. Sci. 109, 12626-12631.

[33] A. Butenandt, W. Weidel and E. Becker (1940). Kynurenin als Augenpigmentbildung auslösendes Agens bei Insekten, Naturwissenschaften 28, 63-64.

[34] G.W. Beadle and B. Ephrussi (1936). The differentiation of eye pigments in Drosophila as studied by transplantation, Genetics 21, 225-247.

[35] P.J. Wittkopp and P. Beldade (2009). Development and evolution of insect pigmentation: genetic mechanisms and the potential consequences of pleiotropy, Sem. Cell Devel. Biol. 20, 65-71.

[36] H.F. Nijhout (2010). Molecular and physiological basis of colour pattern formation, Adv. Insect Physiol. 219-265.

[37] M. Riou and J.-P. Christidès (2010). Cryptic color change in a crab spider (Misumena vatia): identification and quantification of precursors and ommochrome pigments by HPLC, J. Chem. Ecol. 36, 412-423.

[38] M. Osanai-Futahashi, K. Tatematsu, R. Futahashi, J. Narukawa, Y. Takasu, T. Kayukawa, T. Shinoda, T. Ishige, S. Yajima, T. Tamura, K. Yamamoto and H. Sezutsu (2016). Positional cloning of a Bombyx pinkeyed white egg locus reveals the major role of cardinal in ommochrome synthesis, Heredity 116, 135145 .

[39] A. Bolognese and R. Liberatore (1988). Photochemistry of ommochrome pigments, J. Het. Chem. 25, 1243-1246.

[40] S. Vogliardi, A. Bertazzo, S. Comai, C.V.L. Costa, G. Allegri, R. Seraglia and P. Traldi (2004). An investigation on the role of 3-hydroxykynurenine in pigment formation by matrix-assisted laser desorption/ionization mass spectrometry, Rapid Commun. Mass Spectrom. 18, 1413-1420.

[41] E.V. Daniels and R.D. Reed (2012). Xanthurenic acid is a pigment in Junonia coenia butterfly wings, Biochem. Syst. Ecol. 44, 161-163.

[42] W.B. Dunn, A. Erban, R.J.M. Weber, D.J. Creek, M. Brown, R. Breitling, T. Hankemeier, R. Goodacre, S. Neumann, J. Kopka and M.R. Viant (2012). Mass appeal: metabolite identification in mass spectrometry-focused untargeted metabolomics, Metabolomics 9, 44-66.

[43] Y. Umebachi (1985). Papiliochrome, a new pigment group of butterfly, Zool. Sci. 2, 163-174.

[44] K. Inagami (1955). Chemical and genetical studies on the formation of pigment and metabolism of tryptophan in the silkworm - X. Biochemical studies on the "Red Blood-rb" gene in the silkworm, J.Agric. Chem. Soc. Jpn. 29, 918-921.

[45] K. Inagami (1958). The mechanism of formation of tryptophan pigments and the metabolism of tryptophan in silkworm, Bull. Kumamoto Sericult. Exp. Stat. 6,5-58.

[46] E. Glassman (1956). Kynurenine formamidase in mutants of Drosophila, Genetics 41, 566-574.

[47] A. Egelhaaf (1958). Nachweis eines genabhägigen L-tryptophanoxydase-systems bei Ephestia kühniella, Z. Naturforsch. 13b, 275-279.

[48] C. Baglioni (1959). Genetic control of tryptophan peroxidase-oxidase in Drosophila melanogaster, Nature 184, 1084-1085.

[49] S. Hiraga (1964). Tryptophan metabolism in eye-color mutants of the housefly, Jap. J. Genet. 39, 240253. 
[50] G.A. Marzluf (1965). Tryptophan pyrrolase of Drosophila: partial purification and properties, Zeit. Vererb.-Lehre 97, 10-17.

[51] S. Nawa (1970). Purification and properties of tryptophan pyrrolase in Ephestia, Annu. Rep. Nut. Inst. Genet. 21, 24-25.

[52] D.L. Baillie and A. Chovnick (1971). Studies on the genetic control of tryptophan pyrrolase in Drosophila melanogaster, Molec. Gen. Genet. 112, 341-353.

[53] P. Feigelson and H. Maeno (1967). Studies on enzyme-substrate interactions in the regulation of tryptophan oxygenase activity, Biochem. Biophys. Res. Commun. 28, 289-293 (1967).

[54] C. Baglioni (1960). Genetic control of tryptophan pyrrolase in Drosophila melanogaster and D. virilis, Heredity 15, 87-96.

[55] S. Kaufman (1962). Studies on tryptophan pyrrolase in Drosophila melanogaster, Genetics 47, 807-817.

[56] T.M. Rizki and R.M. Rizki (1963). An inducible enzyme system in the larval cells of Drosophila melanogaster, J. Cell Biol. 17, 87-92.

[57] T.M. Rizki and R.M. Rizki (1964). Factors affecting the intracellular synthesis of kynurenine. J.Cell Biol. 21, 27-33 (1964).

[58] G.A. Marzluf (1965). Enzymatic studies with the suppressor of vermilion of Drosophiln melanogaster, Genetics 52, 503-512.

[59] A. Egelhaaf (1963). Biochemische Wirkungen des $\alpha$-Locus von Ephestia kiihniella in der Ei- und Larvenentwicklung, Zool.Anz. Suppl. 26, 79-84.

[60] F. Leibenguth (1967). Regulation of tryptophan metabolism in the parasitic wasp, Habrobracon juglandis, Experientia 23, 1069-1071.

[61] R. Shinohara and I. Ishiguro (1970). The purification and properties of formamidase from rat liver, Biochim. Biophys. Acta 198, 324-331.

[62] G. Mayer, V.Ullrich and H. Staudinger (1968). Possible involvement of cytochrome $b_{5}$ in L-kynurenine3-hydroxylase of rat liver mitochondria, Hoppe-Seyler's Z. Physiol. Chem. 349, 459-464.

[63] A. Egelhaaf (1963). Über das Wirkungsmuster des $\alpha$-Locus von Ephestia kühniella, Zeit. Vererb.-Lehre 94, 348-384.

[64] D. Ghosh and H.S. Forrest (1967). Enzymatic studies on the hydroxylation of kynurenine in Drosophila melanogaster, Genetics 55, 423-431.

[65] S. Pinamonti, A. Petris and F. Ottaviani (1970). Studio sulla chinurenina-3-idrossilasi in Schistocerca greguria Forsk. (Orthoptera, Arcrididae), Atti Accad. Sci. Ferrara. 48, 1-12.

[66] H. Weissbach and E. Katz (1961). Studies on the biosynthesis of actinomycin: enzymic synthesis of the phenoxazone chromophore, J. Biol. Chem. 236, 17-18.

[67] E. Katz and H. Weissbach (1962). Biosynthesis of the actinomycin chromophore; enzymatic conversion of 4-methyl-3-hydroxyanthranilic acid to actinocin, J. Biol. Chem. 237, 882-886.

[68] P.M. Nair and C.S. Vaidyanathan (1964). Isophenoxazine synthase. Biochim. Biophys. Acta. 81, 507-516.

[69] P.M. Nair and L.C. Vining (1964). An isophenoxazine synthase from Pycnoporus coccineus (Fr.) Bond. and Sing, Can. J. Biochem. 42, 1515-1526.

[70] S. Joshi and R.R. Brown (1959). Pigment formation from hydroxy-kynurenine by a rat liver system, Proc. Fed. Am. Soc. Exptl. Biol. 18, 255.

[71] H.R. Gutmann and H.T. Nagasawa. The oxidation of $o$-aminophenols by cytochrome $c$ and cytochrome oxidase. J. Biol. Chem. 234, 1593-1599 (1959).

[72] L.R. Morgan and D.M. Weimorts (1964). The conversion of 3-hydroxyanthranilic acid to 2aminophenoxazin-3-one-1,8-dicarboxylic acid by extracts of acetone powders of poikilothermic animal livers, Biochim. Biophys. Acta. 82, 645-647.

[73] P.V. Subba Rao, N.S. Jegannathan and C.S. Vaidyanathan (1965). Enzymic conversion of 3hydroxyanthranilic acid into cinnabarinic acid by the nuclear fraction of rat liver, Biochem. J. 95, 628632.

[74] A. Butenandt, E. Biekert and B. Linzen (1956). Über Ommochrome, VII. Mitteilung. Modellversuche zur Bildung des Xanthommatins in vivo, Hoppe-Seyler's Z. Physiol. Chem. 305, 284-289.

[75] A. De Antoni, G. Allegri and C. Costa (1970). Xantommatina per via enzimatica, Gazz. Chim. Ital. 100, 1050-1055.

[76] M. Osanai-Futahashi, K.-i. Tatematsu, K. Yamamoto, J. Narukawa, K. Uchino, T. Kayukawa, T. Shinoda, Y. Banno, T. Tamura and H. Sezutsu (2012). Identification of the Bombyx red egg gene reveals involvement of a novel transporter family gene in late steps of the insect ommochrome biosynthesis pathway, J. Biol. Chem. 287, 17706-17714.

[77] B. Linzen (1970). Zur biosynthese von ommochromen, I. Einbau ${ }^{35} \mathrm{~S}$-markierter vorstufen in ommine, Hoppe-Seyler's Z.Physiol. Chem. 351, 622-628. 
[78] H. Zhang, Y. Lin, G. Shen, X. Tan, C. Lei, W. Long, H. Liu, Y. Zhang, Y. Xu, J. Wu, J. Gu, Q. Xia and P. Zhao (2017). Pigmentary analysis of eggs of the silkworm Bombyx mori, J. Insect Physiol. 101, 142 150.

[79] K.M. Summers, A.J. Howells and N.A. Pyliotis (1982). Biology of eye pigmentation in insects, $A d v$. Insect Physiol. 119-166.

[80] A. Bolognese and G. Scherillo (1974). Occurrence and characterization of a labile xanthommatin precursor in some invertebrates, Experientia 30, 225-226.

[81] J.P. Phillips and H.S. Forrest (1970). Terminal synthesis of xanthommatin in Drosophila melanogaster. II. Enzymatic formation of the phenoxazinone nucleus, Biochem. Genet. 4, 489-498.

[82] M. Yamamoto, A.J. Howells and R.L. Ryall (1976). The ommochrome biosynthetic pathway in Drosophila melanogaster: the head particulate phenoxazinone synthase and the developmental onset of xanthommatin synthesis, Biochem. Genet.14, 1077-1090.

[83] A. Bolognese, R. Liberatore, G. Riente and G. Scherillo (1988). Oxidation of 3-hydroxykynurenine. A reexamination, J. Het. Chem. 25, 1247-1250.

[84] J. Li, B.T. Beerntsen and A.A. James (1999). Oxidation of 3-hydroxykynurenine to produce xanthommatin for eye pigmentation: a major branch pathway of tryptophan catabolism during pupal development in the yellow fever mosquito, Aedes aegypti, Insect Biochem. Mol. Biol. 29, 329-338.

[85] B.M. Stubenhaus, J.P. Dustin, E.R. Neverett, M.S. Beaudry, L.E. Nadeau, E. Burk-McCoy, X. He, B.J. Pearson and J. Pellettieri (2016). Light-induced depigmentation in planarians models the pathophysiology of acute porphyrias, eLife 5, e14175.

[86] X. He, N. Lindsay-Mosher, Y. Li, A.M. Molinaro, J. Pellettieri and B.J. Pearson (2017). FOX and ETS family transcription factors regulate the pigment cell lineage in planarians, Development 144, 4540-4551.

[87] W. Huang, Z. Gong, J. Li and J. Ding (2013). Crystal structure of Drosophila melanogaster tryptophan 2,3-dioxygenase reveals insights into substrate recognition and catalytic mechanism, J. Struct. Biol. 181, 291-299.

[88] H. Michels, R.I. Seinstra, J.C.M. Uitdehaag, M. Koopman, M. van Faassen, C.N. Martineau, I.P. Kema, R. Buijsman and E.A.A. Nollen (2016). Identification of an evolutionary conserved structural loop that is required for the enzymatic and biological function of tryptophan 2,3-dioxygenase, Sci. Rep. 6, 39199.

[89] Q. Han, H. Robinson and J. Li (2012). Biochemical identification and crystal structure of kynurenine formamidase from Drosophila melanogaster, Biochem. J. 446, 253-260.

[90] J.R. Smith, J.F. Jamie and G.J. Guillemin (2016). Kynurenine-3-monooxygenase: a review of structure, mechanism, and inhibitors, Drug Discov. Today 21, 315-324.

[91] M. Amaral, C. Levy, D.J. Heyes, P. Lafite, T.F. Outeiro, F. Giorgini, D. Leys and N.S. Scrutton (2013). Structural basis of kynurenine 3-monooxygenase inhibition, Nature 496, 382-385.

[92] J. Gao, L. Yao, T. Xia, X. Liao, D. Zhu and Y. Xiang (2018). Biochemistry and structural studies of kynurenine 3-monooxygenase reveal allosteric inhibition by Ro 61-8048, FASEB J. 32, 2036-2045.

[93] J.L. Rasgon and T.W. Scott. Crimson: a novel sex-linked eye color mutant of Culex pipiens L. (Diptera: Culicidae), J. Med. Entomol. 41, 385-391.

[94] D.A. Harris, K. Kim, K. Nakahara, C. Vásquez-Doorman and R.W. Carthew (2011). Cargo sorting to lysosome-related organelles regulates siRNA-mediated gene silencing. J. Cell Biol. 194, 77-87.

[95] P. Santoro and G. Parisi (1987). Biosynthesis of dihydroxanthommatin, Insect Biochem. 17, 635-638.

[96] H.F. Nijhout (1991) The Development and Evolution of Butterfly Wing Patterns. Smithsonian Inst. Press, Washington, DC, USA, pp. 297.

[97] Y. Umebachi and A. Nakamura (1954). The presence of kynurenine in the wings of the papilionid butterflies, Zool. Mag. Tokyo. 63, 57-61.

[98] Y. Umebachi and H. Takahashi (1956). Kynurenine in the wings of the papilionid butterflies, J. Biochem. Tokyo. 43, 73-81.

[99] Y. Umebachi (1958). Yellow pigments in the wings of the papilionid butterflies - I. The relation between kynurenine and the yellow pigments of Papilio xuthus, Sci. Rep. Kanazawa Univ. 6, 45-55.

[100] Y. Umebachi (1959). Yellow pigments in the wings of the papilionid butterflies - II. The presence of a pale blue fluorescent substance supposed to be kynurenine in the wings of the Zerynthiinae, Sci.Rep. Kanazawa Univ. 6, 69-75.

[101] Y. Umebachi (1959). Yellow pigments in the wings of the papilionid butterflies - III. The Radioautographs of the wings of five species of Papilio injected with ${ }^{14} \mathrm{C}$-labeled tryptophan, Annot. Zool. Jpn. 32, 112-116.

[102] Y. Umebachi (1960). Yellow pigments in the wings of the papilionid butterflies - IV. The presence or absence of kynurenine in the wings of the genus Graphium. Sci. Rep. Kanazawa Univ. 7, 107-112.

[103] Y. Umebachi (1961). Yellow pigments in the wings of the papilionid butterflies - V. Some chemical properties of the yellow pigments of Papilio xuthus. Sci. Rep. Kanazawa Univ. 7, 139-150. 
[104] Y. Umebachi (1962). Yellow pigments in the wings of the papilionid butterflies - VII. Consideration of the nature and distribution of the wing pigments of the papilionid butterflies, Sci.Rep. Kanazawa Univ. 8, 135-142.

[105] Y. Umebachi and M. Yamada (1964). Tryptophan and tyrosine metabolism in the pupa of papilionid butterflies - I. Accumulation of the bound form of kynurenine in Pupilio Xuthus, Annot. Zool. Japon. 37, 51-57.

[106] Y. Umebachi and M. Katayama (1966). Tryptophan and tyrosine metabolism in the pupa of papilionid butterflies - II. The general pattern of tryptophan metabolism during the pupal stage of Papilio xuthus. $J$. Insect Physiol. 12,1539-1547.

[107] Y. Umebachi and K. Yoshida (1970). Some chemical and physical properties of papiliochrome II in the wings of Papilio Xuthus, J. Insect Physiol. 16, 1203-1228.

[108] Y. Umebachi (1975). Yellow pigments in the wings of Papilio xuthus (papilionid butterfly), Acta Vitaminol. Enzymol. 29, 219-222.

[109] Y. Umebachi and H. Yamashita (1977). $\beta$-Alanine as a constituent of the dopamine derivative, SN-1 of Papilio xuthus. Comp. Biochem. Physiol. Part B: Comp. Biochem. 56, 5-8.

[110] H. Rembold, J. Rascher, J. Eder and Y. Umebachi (1978). Partial structure of papiliochrome, the yellow wing pigment of the papilionid butterflies, Z. Naturforsch. C 33, 498-503.

[111] Y. Umebachi and H. Yamashita (1976). Clear evidence for the presence of $\beta$-alanine as a constituent of papiliochrome II, Comp. Biochem. Physiol. Part B: Comp. Biochem. 54, 55-62.

[112] H. Rembold and Y. Umebachi (1984). The structure of papiliochrome 1I, the yellow wing pigment of the papilionid butterflies. In: Progress in Tryptophan and Serotonin Research, eds: H.G. Schlossberger, W. Kochen, B. Lenzen, and H. Steinhart, W. de Gruyter \& Co., Berlin, Germany, pp. 743-746.

[113] Y. Ishizaki and Y. Umebachi (1984). Synthesis, accumulation and excretion of kynurenine during the pupal and adult stages of Papilio xuthus. Insect Biochem. 14, 563-567.

[114] Y. Umebachi and Y. Ishizaki (1986). Accumulation and excretion of beta-alanine in Papilio xuthus (Lepidoptera: Papilionidae). Comp. Biochem. Physiol. 85B, 503-506.

[115] Y. Ishizaki and Y. Umebachi (1988). Level changes of $\beta$-alanine, dopamine, and $N$ - $\beta$-alanyldopamine during the pupal stage of Papilio xuthus (Lepidoptera: Papilionidae), Comp. Biochem. Physiol. 90C, 8387.

[116] M. Yago (1989). Enzymic synthesis of papiliochrome II, a yellow pigment in the wings of papilionid butterflies, Insect Biochem. 19, 673-678.

[117] Y. Umebachi (1989). Kynurenine, $\beta$-alanine, and dopamine in the deep yellow pigment of Papilio machaon (Lepidoptera: Papilionidae), Comp. Biochem. Physiol. Part B: Comp. Biochem. 94, 207-211.

[118] M. Sugumaran, S.J. Saul and H. Dali (1990). On the mechanism of side chain oxidation of $N-\beta-$ alanyldopamine by cuticular enzymes from Sarcophaga bullata, Arch. Insect Biochem. Physiol. 15, 255 269.

[119] S.J. Saul and M. Sugumaran (1991). Quinone methide as a reactive intermediate formed during the biosynthesis of papiliochrome II, a yellow wing pigment of papilionid butterflies, FEBS Lett. 279, 145148.

[120] S.J. Saul, H. Dali and M. Sugumaran (1991). Quinone and quinone methide as transient intermediates involved in the side chain hydroxylation of $N$-acyldopamine derivatives by soluble enzymes from Manduca sexta cuticle, Arch. Insect Biochem. Physiol. 16, 123-138.

[121] P.B. Koch, B. Behnecke, M. Weigmann-Lenz and R.H. Ffrench-Constant (2000). Insect pigmentation: activities of $\beta$-alanyldopamine synthase in wing color patterns of wild-type and melanic mutant swallowtail butterfly Papilio glaucus, Pigm. Cell Res. 13, 54-58.

[122] G. Shamim, S.K. Ranjan, D.M. Pandey and R. Ramani (2014). Biochemistry and biosynthesis of insect pigments, Eur. J. Entomol. 111, 149-164.

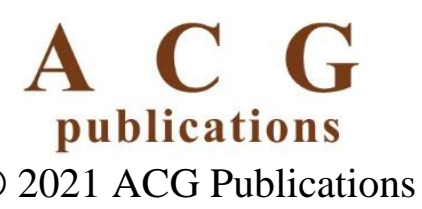

